\title{
Effect of 20-methylcholanthrene on amphibian natural killer cells
}

\author{
I. A. Sadek ${ }^{1, *}$, M. Ghoneum ${ }^{2}$, E. L. Cooper ${ }^{3}$ \\ ${ }^{1}$ Department of Zoology, Faculty of Science, University of Alexandria, Egypt \\ ${ }^{2}$ Department of Otolaryngology, Charles R. Drew University of Medicine and Science, Los Angeles, California, USA \\ ${ }^{3}$ Department of Anatomy, UCLA School of Medicine, Los Angeles, California, USA
}

\begin{abstract}
Effects of the chemical carcinogen 20-methylcholanthrene (MC) on toad Bufo marinus natural killer (NK) cells were tested in vivo and in vitro. Toads fed with MC ( $5 \mathrm{mg} \mathrm{toad}^{-1}$ once per wk) mixed with olive oil exhibited an initial increase in NK activity at $10 \mathrm{~d}$, followed by a suppression (60\%) at 20 and $30 \mathrm{~d}$ compared to control toads fed only olive oil. Conjugate formation was examined and demonstrated a slight decrease. Leukocytes which were preincubated with $\mathrm{MC}$ (5 to $100 \mu \mathrm{g} \mathrm{ml} \mathrm{m}^{-1}$ ) at room temperature for $1 \mathrm{~h}$, and afterwards washed 3 times, had lowered NK activity $(47$ to $85 \%$ ). In conclusion, the observed inhibition of NK cell activity by MC may predispose toads to carcinogenesis by a mechanism similar to that which occurs in mammals.
\end{abstract}

\section{INTRODUCTION}

Amphibian tumors have been studied by several workers (Khudoley \& Picard 1980, Sadek 1981, 1986a) More recently, it has been reported that chemical carcinogens induced tumors in the Egyptian toad (Sadek 1986b, Sadek \& Abdelmeguid 1986). Multiple effects of chemical carcinogens on various homeostatic regulatory mechanisms, including the immune system, have been demonstrated during the extremely complicated process of carcinogenesis (Kalland 1984). The immune surveillance theory implies that chemical carcinogens would suppress certain immunocompetent cells, enabling cells with malignant potential, which would otherwise be eliminated, to survive (Herberman 1984).

The idea of immune surveillance has gained renewed interest with the discovery of natural killer (NK) cells which do not require prior sensitization in order to destroy certain tumor cells. Accumulating evidence supports the assumption that NK cells may be part of the natural defense against tumors (Herberman 1983). A decrease in activity of NK cells has been reported in animals treated with chemical carcinogens such as methylcholanthrene (MC) (Ghoneum et al. 1987b), dimethylbenzanthracene (DMBA) (Ehrlich et al. 1983) and urethane (Gorelick \& Herberman 1981) In addition, $\mathrm{MC}$ is a potent inhibitor of mouse $\mathrm{NK}$ activity in vitro (Kalland 1984).

\footnotetext{
- Addressee for correspondence
}

Clearly, amphibians have a well-developed immune system that consists of major cellular and humoral components (Cooper 1986). Recently, our studies showed that the immune system of frogs possesses inducible killer (IK) cells (CTL-like) and spontaneous (SK) cells (NK-like) which effect lytic responses against allogeneic cells (Ghoneum \& Cooper 1987, Ghoneum et al. 1987a). In this paper, we report on studies aimed at analysing the effects of MC on NK activity in vivo and in vitro in the toad Bufo marinus. Our eventual goal is to examine the evolutionary basis of immune responses towards $\mathrm{MC}$ challenge.

\section{MATERIALS AND METHODS}

Animals. Sexually mature male and female toads Bufo marinus, were used in this study. The toads were obtained from St. Croix Biological, Stillwater, Minnesota, USA. They were kept in plastic pans with water which was changed twice weekly. The average weight per experimental toad was $270 \mathrm{~g}$. Toads were fed meal worms twice per week when the water was changed, and acclimated to the laboratory for $2 \mathrm{wk}$ prior to the experiments.

Preparation of peripheral blood leukocytes (PBL). Toads were sacrificed after anesthetization with ether. Heparinized peripheral blood was obtained by cardiac puncture. The blood was centrifuged in Wintrobe tubes, the buffy coat was carefully removed, washed 
twice in Amphibian Ringer Solution (ARS) and finally effector cells were adjusted to $10 \times 10^{6}$ cells mil (Ghoneum \& Cooper 1987, Ghoneum et al. 1987a).

Target cells. The YAC-1 tumor cell line, a Maloney Leukemia virus-induced mouse T-cell lymphoma of $A$ Sn mouse origin, was maintained in our laboratory in complete medium (CM) at a starting concentration of $3 \times 10^{5}$ cells $\mathrm{ml}^{-1}$

Complete medium (CM). CM consisted of RPMI1640, supplemented with $10 \%$ heat-inactivated fetal calf serum (FCS) and $1 \%$ antibiotics $\left(100 \mu \mathrm{g} \mathrm{mi}^{-1}\right.$ penicillin and $100 \mu \mathrm{g} \mathrm{ml}^{-1}$ streptomycin).

Methylcholanthrene. 20-methylcholanthrene (MC) was purchased from Sigma Chemical Company, St. Louis, Michigan, USA. For in vivo experiments, MC was dissolved in olive oil (Sigma Chemical Company, St. Louis, Michigan, USA). Experimental toads were fed (by esophageal tubing) $5 \mathrm{mg}^{\text {toad }}{ }^{-1}$ of $\mathrm{MC}$ dissolved in $0.1 \mathrm{ml}$ of olive oil once per wk for $30 \mathrm{~d}$. Control toads were fed $0.1 \mathrm{ml}$ olive oil once per wk. For in vitro experiments, $\mathrm{MC}$ was diluted in buffer and dissolved in dimethylsulfoxide (DMSO) at concentrations of 5,20 and $100 \mu \mathrm{g} \mathrm{ml} \mathrm{m}^{-1}$ in $5 \mu \mathrm{l}$ DMSO Leukocytes were preincubated with $\mathrm{MC}$ at room temperature for $1 \mathrm{~h}$.

Cytotoxic assay. YAC- 1 target cells $\left(5 \times 10^{6}\right.$ cells $)$ cultured for $24 \mathrm{~h}$ were labelled with $100 \mu \mathrm{Ci}$ sodium chromate solution (New England Nuclear, Boston, Massachusetts, USA) for $1 \mathrm{~h}$ in $0.1 \mathrm{ml} \mathrm{CM}$ and washed 3 times in $5 \mathrm{ml} \mathrm{CM} \mathrm{Hanks}$ balanced salt solution (HBSS) as previously described by Ghoneum et al. $1987 \mathrm{~b}$. Target cells $\left(1 \times 10^{4}\right)$ in $0.1 \mathrm{ml} \mathrm{CM}$ were pipetted into 96 well-round bottom Linbro plates (Linbro Chemical Co., Hamden, Connecticut, USA). Effector cells were suspended at $10 \times 10^{6} \mathrm{ml} \mathrm{ARS}$, and $0.1 \mathrm{ml}$ pipetted into quadruplicate wells to give effector:target (E:T) cell ratios of 100:1,50:1 and 25:1. Following 4 h at room temperature, plates were centrifuged at $1400 \mathrm{rpm}$ $(400 \times \mathrm{g})$ for $5 \mathrm{~min}$, and the supernatant $0.1 \mathrm{ml}$ from each well was collected and counted in triplicate in a Gamma counter. The percentage of isotope released was calculated using the following formula:

$\%$ lysis $=\frac{\text { Counts } \min ^{-1} \text { exptI rel. }- \text { Counts } \min ^{-1} \mathrm{sp} \cdot \text { rel. }}{\text { Counts } \min ^{-1} \max \cdot \text { rel. }- \text { Counts } \min ^{-1} \text { sp. rel. }} \times 100$

Spontaneous release (sp. rel.) from the target cells was always 8 to $10 \%$ of total release. Maximum release (max. rel.), was measured by adding $0.1 \mathrm{ml}$ Triton X100 to designated wells. Percent target cell lysis for different $\mathrm{E}: \mathrm{T}$ ratios used to construct effector titration.

Conjugate formation. Leukocytes $\left(1 \times 10^{5}\right)$ were incubated with $1 \times 10^{6}$ YAC- 1 target cells in $1 \mathrm{ml}$ of ARS in $12 \times 75 \mathrm{~mm}$ glass tubes, sedimented by centrifugation at $130 \times \mathrm{g}$ for $5 \mathrm{~min}$ and incubated for $1 \mathrm{~h}$ at $4{ }^{\circ} \mathrm{C}$. Pellets were resuspended and cytocentrifuged smears stained with Giemsa. The percent of conjugates were examined by counting 200 lymphocytes (bound and free) in triplicate samples (Kumagai et al. 1982)

Lytic units (LU). LUs were calculated from effector titration curves according to our previously demonstrated procedure (Ghoneum et al. 1987b). One LU was defined as the number of effector cells required to achieve $10 \%$ lysis. LU/ $10^{7}$ is the number of LUs in 10 million effector cells.

Statistical analysis. A 2-tailed Student's t-test was used to determine the significance of differences between different experimental groups.

\section{RESULTS}

An initial increase in NK activity in MC-treated toads was observed. However, a statistically significant depression of NK activity occurred at subsequent time periods. MC-fed toads revealed a 15,40 and $45 \%$ decrease in NK activity at $20 \mathrm{~d}$ for effector:target ( $E: T$ ) ratios of $25: 1,50: 1$ and 100:1 respectively. This suppression became more intensified at $30 \mathrm{~d}$, and showed 85,68 and $52 \%$ at $25: 1,50: 1$ and $100: 1$ respectively (Table 1).

$\mathrm{MC}$ induced inhibition of $\mathrm{NK}$ activity in vitro (Table 2). Leukocytes which were pre-incubated with $\mathrm{MC}$ at room temperature for $1 \mathrm{~h}$, and washed 3 times afterwards with ARS, exhibited inhibition of NK activity $\left(47\right.$ to $85 \%$ ) at 5 to $100 \mu \mathrm{g} \mathrm{ml} \mathrm{m}^{-1}$. MC-treated toads revealed no statistically significant change in conjugate formation when compared to control toads (Fig. 1a). Similarly, MC did not interfere with binding capacity of NK cells when cultured with PBL in vitro for $1 \mathrm{~h}$ (Fig. 1b).

Table 1. Bufo marinus. In vivo effect of MC on NK activity in toads. Data are means \pm SD of 5 different toads in each group

\begin{tabular}{|c|c|c|c|c|}
\hline \multirow{2}{*}{$\begin{array}{l}\text { Days post-MC } \\
\text { treatment }\end{array}$} & \multicolumn{3}{|c|}{$\%$ of cytotoxicity ${ }^{\mathrm{a}}$} & \multirow[t]{2}{*}{ LU } \\
\hline & $25: 1^{\mathrm{b}}$ & $50: 1^{b}$ & $100: 1^{\mathrm{b}}$ & \\
\hline \multirow[t]{2}{*}{ Control } & & & 18.6 & \multirow[t]{2}{*}{22.2} \\
\hline & \pm 1.1 & \pm 2.1 & \pm 3.7 & \\
\hline \multirow[t]{2}{*}{10} & 10.3 & 16.9 & 23.6 & \multirow[t]{2}{*}{40} \\
\hline & \pm 4.3 & \pm 4.6 & \pm 3.4 & \\
\hline \multirow[t]{2}{*}{20} & 3.9 & 5.9 & 10.2 & \multirow[t]{2}{*}{$9.2^{\circ}$} \\
\hline & \pm 2.8 & \pm 2.7 & \pm 2.8 & \\
\hline \multirow[t]{2}{*}{30} & 0.7 & 3.1 & 8.9 & \multirow[t]{2}{*}{$6.7^{\cdots}$} \\
\hline & \pm 0.3 & \pm 1.1 & \pm 2.5 & \\
\hline \multicolumn{5}{|c|}{$\begin{array}{l}\text { a Cytotoxicity assay is a } 4 \mathrm{~h}^{51} \mathrm{Cr}-\text { release assay } \\
\text { b } 25: 1,50: 1 \text { and } 100: 1 \text { representing dilution steps of effec- } \\
\text { tor to target cells } \\
\cdot p<0.05 ; \cdots p<0.001\end{array}$} \\
\hline
\end{tabular}




\section{DISCUSSION}

The attention of some tumor immunologists has recently focused on natural immunity as a possible first line of defense against transformed cells progressing toward malignancy (Herberman 1983, Ghoneum et al. 1987b). Immunosuppression induced in experimental animals by chemical carcinogens such as methylchoanthrene is thought to play a major role in malignant tumor development in these hosts (Herberman 1982). In this work, we wanted to test the effect of MC on NK cell activity in ectothermic vertebrates (e.g. toads) in order to compare this effect with mammals. The results clearly show that MC suppresses NK activity in toads in vivo and in vitro.

The mechanism of suppression in NK activity induced by $\mathrm{MC}$ is generally unknown and according to

Table 2. Bufo marinus. In vivo effect of $\mathrm{MC}$ on toad NK activity. Data are means $\pm S D$ of 5 different toads in each group

\begin{tabular}{|c|c|c|c|c|}
\hline \multirow{2}{*}{$\begin{array}{l}\text { Dose } \\
\left(\mu g \mathrm{ml}^{-1}\right)\end{array}$} & \multicolumn{3}{|c|}{$\%$ of cytotoxicity ${ }^{a}$} & \multirow[t]{2}{*}{ LU } \\
\hline & $25: 1^{b}$ & $50: 1^{b}$ & $100: 1^{b}$ & \\
\hline 0 & $\begin{array}{r}4.6 \\
+1.1\end{array}$ & $\begin{array}{r}9.8 \\
+2.1\end{array}$ & $\begin{array}{r}18.8 \\
\pm \quad 3.7\end{array}$ & 22.2 \\
\hline 5 & $\begin{array}{r}3.0 \\
\pm 0.9\end{array}$ & $\begin{array}{r}5.2 \\
\pm 1.6\end{array}$ & $\begin{array}{r}12.0 \\
\pm \quad 3.6\end{array}$ & $11.8^{\circ}$ \\
\hline 20 & $\begin{array}{r}2.0 \\
\pm 0.5\end{array}$ & $\begin{array}{r}4.6 \\
\pm 1.5\end{array}$ & $\begin{array}{r}5.0 \\
+\quad 1.2\end{array}$ & $6.9^{*}$ \\
\hline 100 & $\begin{array}{r}10 \\
\pm 0.4\end{array}$ & $\begin{array}{r}1.2 \\
\pm 0.6\end{array}$ & $\begin{array}{l}3 \\
+\quad 1.0\end{array}$ & $3.3^{*}$ \\
\hline \multicolumn{5}{|c|}{ ab As in Table 1} \\
\hline
\end{tabular}

Herberman (1983), may be due to interference with effector mechanisms by such chemical carcinogens. Previous studies suggest that environmental chemicals and tumor promoters interfere with $\mathrm{T}$-cell function and NK activity, which may facilitate tumor growth (Dean et al. 1982). It has been shown that the polycyclic aromatic hydrocarbons (PAH) alter $T$-cell function and induce suppressor T-cells (Alfred et al. 1982, Wojdani et al. 1984). We have previously detected inhibition in $\mathrm{NK}$ activity in $\mathrm{C} 3 \mathrm{H}$ mice as early as $10 \mathrm{~d}$ post-treatment with MC (Ghoneum et al. 1987b); the decrease in NK activity may be due to non-specific toxic effects of MC on NK cells. Additionally, another PAH compound, DMBA, has been demonstrated to have an inhibitory effect on murine NK activity (Ehrlich et al. 1983), and MC suppressive effects on NK cells in vitro has been reported (Kalland 1984). In conclusion, MC inhibits the lytic activity of NK cells in toads against YAC-1 target cells. The latter conclusion may clarify the process of carcinogenesis of MC in Egyptian toads (Sadek 1981, Sadek \& Abdelmeguid 1986), which appears to be similar to mammals. Future experiments in this laboratory will attempt to define the mechanism of action of $\mathrm{MC}$ on cell-mediated immune (CMI) function and its relationship to immunosurveillance in toads. This will hopefully provide a better understanding of the evolutionary basis of immune responses to tumor growth.

Acknowledgement. This work was partially supported by Fulbright Grant No. 253
Fig. 1. Bufo marinus, Effect of $\mathrm{MC}$ on conjugate formation between NK and YAC-1 cells (a) in vivo and (b) in vitro

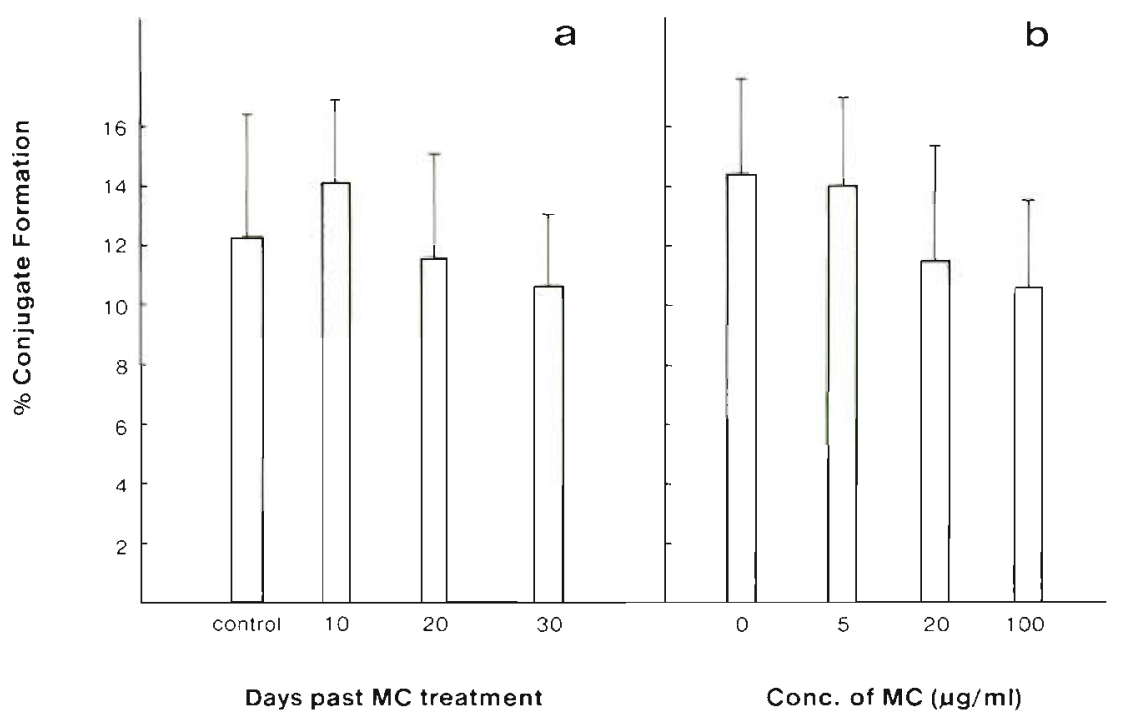




\section{LITERATURE CITED}

Alfred, L. J., Wojdani, A., Neito, M., Perez, R., Yoshida, G. (1982). A chemical carcinogen, 3-methylcholanthrene, alters $\mathrm{T}$-cell function and induces $\mathrm{T}$-suppressor cells in a mouse model system. Immunology 50: 207-214

Cooper, E. L. (1976). Immunity mechanisms. In: Lofts, B. (ed.). Physiology of Amphibia, Vol. 3. Academic Press, New York, p. 164-272

Dean, J. H., Luster, M. I., Boorman, G. A., Lauer, L. D., Ward, E. C. (1982). Immunotoxicity of tumor promoting environmental chemicals and phorbol diesters. In: Hadden, J. W., Chedid, L., Dukor, P., Spreafico, F., Willoughby, D. (eds.) Advances in immunopharmacology. Pergamon Press, Oxford, p. 23-31

Ehrlich, R., Efrati, M., Malatsky, E., Shochat, L., Bar-Eyal, A., Witz, I. P. (1983). Natural host of defense during oncogenesis: NK activity on dimethylbenzanthracene carcinogenesis. Int. J. Cancer 31.67-73

Ghoneum, M., Cooper, E (1987). Inhibition of frog SK effector: target cell binding. Dev. Comp. Immunol. 11. 167-179

Ghoneum, M.. Cooper, E., Smith, C. (1987a). Factors affecting inhibition of spontaneous cytotoxic cells in frogs. Dev. Comp. Immunol. 11: 363-373

Ghoneum, M., Gill, G., Wojdani, A., Payne, C., Alfred, L. J. (1987b). Suppression of basal and corynebacterium parvum-augmented NK activity during chemically induced tumor development. Int. J. Immunopharm. 9: 71-78

Gorelick, E. Herberman, R. B. (1981). Inhibition of the activity of mouse NK cells by urethane. J. Natl Cancer Inst. 66: $543-548$
Herberman, R. B. (1983). Natural killer cells and tumor immunity. Surv. Immun. Res. 2; 306-308

Herberman, R. B. (1984). Possible role of natural killer cells and other effector cells in immune surveillance against cancer J. Invest. Dermatol 83: 1375-1405

Kalland, T (1984). The effect of 3-methylcholanthrene on mouse natura] killer cells in vitro. In.t. J. Immunopharmac. 6: 299-305

Khudoley, V V., Picard, J. J. (1980). Liver and kidney tumors induced by $\mathrm{N}$-nitraso-dimethylamine in Xenopus borealis (Parke). Int. J. Cancer 25: 679-683

Kumagai, K., Itoh, K., Suzuki, R., Hinuma, S., Sitoh, F. (1982). Studies of murine large granular lymphocytes. I. Identifi. cation as effector cells in NK and $\mathrm{K}$ cytotoxicities. J. Immunol. 129: 388-394

Sadek, I. A. (1981). Vitamin A and its inhibitory effect as tested on. Egyptain toads. Oncology 38: 23-26

Sadek, I. A. (1986a). Effect of cholic on tumor in Egyptain toad. Oncology 43: 258-270

Sadek, I. A. (1986b). The Egyptian toad as a sensitive model to show the effect of corn oil on liver tumor induced by DMBA. Nutr. Res, 6: 333-335

Sadek, I. A., Abdelmeguid, N. (1986). Enhancement of liver tumor in the Egyptian toad by oral contraceptive steroids J. Nutr. Growth and Cancer 3: 239-244

Woojdani, A., Attarzadeh, M., Wolde-Tsadik, G., Alfred, L. J. (1984). Immunotoxicity effects of polycyclic aromatic hydrocarbons on mouse lymphocytes. Toxicology 31 : 181-189 